\title{
Pelatihan Keterampilan Kain Perca untuk Mengurangi Limbah Anorganik
}

\author{
${ }^{1}$ Novi Ayu Kristiana Dewi, ${ }^{\mathbf{2}}$ Rani Pratiwi, ${ }^{3}$ Lucky Muzayyanah \\ ${ }^{123}$ Prodi Sistem Informasi, STMIK Pringsewu, Jl. Wisma Rini No. 9 Pringsewu, Lampung, \\ Indonesia 35373
}

\section{Email Korespondensi: noviayudi@gmail.com}

\begin{tabular}{|c|c|}
\hline Article Info & Abstract \\
\hline $\begin{array}{l}\text { Article History } \\
\text { Received: } 2020-04-07 \\
\text { Revised: } 2020-06-19 \\
\text { Published: } 2020-06-30\end{array}$ & \multirow{2}{*}{$\begin{array}{l}\text { Patchwork Cloth Skills Training to Reduce Inorganic Waste. The purpose of } \\
\text { this community service activity is to provide education about the dangers of } \\
\text { inorganic waste to the environment and health and to provide training in how } \\
\text { to treat inorganic waste in the form of patchwork so that it has value and } \\
\text { economic value. This dedication was carried out in Sumber Baru Village, } \\
\text { Central Lampung District because based on the results of a survey of } 4 \text { home } \\
\text { tailors in Sumber Baru Village, they did not yet know how to utilize patchwork } \\
\text { waste. The method used is PRA (Participatory Rural Appraisal). The results of } \\
\text { PKM activities are 1) the formation of Partners' knowledge and understanding } \\
\text { of the processing of parca cloth, 2) the formation of partners' skills in } \\
\text { processing waste parca cloth into products that have economic value, and 3) } \\
\text { the formation of partners' concern for environmental pollution due to waste of } \\
\text { parca cloth. Parca fabric waste management training activities are still limited } \\
\text { to making veil accessories such as bross and bandana, so other innovations } \\
\text { need to be done so that the waste can be utilized optimally. In addition, } \\
\text { assistance still needs to be carried out until the production, packaging and } \\
\text { marketing stages }\end{array}$} \\
\hline $\begin{array}{l}\text { Keywords } \\
\text { skills training; } \\
\text { patchwork; } \\
\text { inorganic waste }\end{array}$ & \\
\hline Infor & Abstrak \\
\hline $\begin{array}{l}\text { Sejarah Artikel } \\
\text { Diterima: 07-04-2020 } \\
\text { Direvisi: } 19-06-2020 \\
\text { Dipublikasi: } 30-06-2020\end{array}$ & \multirow{2}{*}{$\begin{array}{l}\text { Tujuan dari kegiatan pengabdian masyarakat ini adalah untuk memberikan } \\
\text { edukasi tentang bahaya limbah anorganik bagi lingkungan dan kesehatan serta } \\
\text { memberikan pelatihan cara pengolahan limbah anorganik berupa kain perca } \\
\text { sehingga memiliki nila guna dan nilai ekonomi. Pengabdian ini dilakukan di } \\
\text { Desa sumber Baru Kecamatan Lampung Tengah karena berdasarkan hasil } \\
\text { prasurvei dari } 4 \text { penjahit rumahan di Desa Sumber Baru tersebut belum tahu } \\
\text { cara memanfaatkan limbah kain perca. Metode yang digunakan adalah PRA } \\
\text { (Participatori Rural Appraisal). Hasil dari kegiatan PKM adalah 1) } \\
\text { terbentuknya pegetahuan dan pemahaman Mitra tentang pengolahan kain parca, } \\
\text { 2) terbentuknya keterampilan mitra dalam mengolah limbah kain parca menjadi } \\
\text { produk yang memiliki nilai ekonomis, dan 3) terbentuknya kepedulian mitra } \\
\text { terhadap pencemaran lingkungan akibat limbah kain parca. Kegiatan pelatihan } \\
\text { pengolahan limbah kain parca masih sebatas pada pembuatan asesoris jilbab } \\
\text { seperti bross dan bandana, sehingga perlu dilakukan inovasi-inovasi yang lain } \\
\text { agar limbah parca dapat dimanfaatkan secara maksimal. Selain itu masih perlu } \\
\text { dilakukan pendampingan sampai tahap produksi, pengemasan dan pemasaran. }\end{array}$} \\
\hline $\begin{array}{l}\text { Kata kunci } \\
\text { pelatihan keteram! } \\
\text { kain perca; } \\
\text { limbah anorganik }\end{array}$ & \\
\hline & \\
\hline
\end{tabular}

\section{PENDAHULUAN}

Limbah adalah buangan yang dihasilkan dari suatu proses produksi baik industri maupun domestik. Salah satu jenis limbah adalah sampah. Sampah merupakan sisa atau barang buangan yang sudah tidak digunakan dan dipakai lagi oleh pemiliknya (Taufiq, 2015). 
Limbah dibedakan menjadi dua, yaitu limbah organik dan anorganik. Limbah organik adalah limbah yang diperoleh dari sisa-sisa mahkluk hidup yang dapat mengalami pembusukan dan bisa diuraikan oleh bakteri pengurai, sedangkan limbah anorganik adalah limbah yang dihasilkan dari bahan-bahan nonhayati baik berupa produk sintetik maupun hasil proses teknologi pengelolahan bahan tambang atau sumber daya alam yang susah bahkan tidak dapat diuraikan oleh bakteri di alam atau memerlukan waktu yang cukup lama untuk penguraiannya hingga ratusan tahun lamanya. Sampah anorganik adalah sampah yang tidak dapat mengalami pembusukan, seperti: botol plastik, tas plastik, kaleng, dan kain (Marliani, 2015).

Kain perca merupakan kain sisa guntingan yang berasal dari pembuatan pakaian atau produk garmen lainnya. Kain perca bisa diperoleh dari penjahit rumahan bahkan perusahaan konveksi. Bagi masyarakat awam kain perca biasanya dianggap sebagai sampah yang tidak bermanfaat sehingga akan menghasilkan limbah anorganik pada lingkungan sekitar yang akhirnya akan mengaggu kebersihan dan kesehatan.

Limbah anorganik dari kain perca memberikan beberapa dampak serius bagi lingkungan dan kesehatan apabila tidak ditangani dengan baik. Dampak buruk tersebut antara lain:1) Merusak biota di dalam tanah dalam jangka waktu tertentu seperti organisme dan fauna tanah. Organisme tanah berperan dalam proses dekomposi bahan organik, distribusi, dan pencampuran bahan organik serta musuh bagi patogen yang menyerang tanaman, sehingga organisme tanah sangat penting dalam membantu pertumbuhan dan produktivitas tanaman (Widyati, 2013). Oleh karena itu, rusaknya biota tanah akan merusak kesuburan dari tanah itu sendiri yang berpengaruh terhadap produktivitas tanaman. 2) Kain perca yang dibakar akan menghasilkan emisi gas rumah kaca.

Gas rumah kaca merupakan gas di atmosfer yang berfungsi menyerap radiasi inframereah dan menentukan suhu atmosfer (Fauziawan, 2018). Jenis gas rumah kaca di atmosfer antara lain: $\mathrm{CO}_{2}, \mathrm{CH}_{4}, \mathrm{~N}_{2} \mathrm{O}$, HFCs, PFCs, dan $\mathrm{SF}_{6}$ (Samiaji, 2010). Dari semua gas tersebut, gas rumah kaca utama penyebab pemanansan global adalah $\mathrm{CO}_{2}, \mathrm{CH}_{4}, \mathrm{~N}_{2} \mathrm{O}$ (Sihombing, 2012). Kain merupakan senyawa turunan dari hidrokarbon, seperti: kain kapas, wol (merupakan suatu protein), sutra (protein), nilon (polimer), dan serat sintetis. Proses pembakaran sempurna senyawa hidrokarbon dan turunannya dibutuhkan oksigen sehingga dihasilkan gas karbon dioksida $\left(\mathrm{CO}_{2}\right)$ dan uap air (Sari \& Fatkhurrahman, 2015). Gas karbon dioksida diketahui sebagai gas yang berperan menyumbang emisi gas rumah kaca terbesar di bumi.

Meningkatnya kuantitas emisi gas rumah kaca diyakini menjadi penyebab pemanasan global dan berpotensi mengancam kehidupan manusia serta keseimbangan ekosistem, lebih lanjut dijelaskan bahwa Intergovernmental Panel on Climate Chage (IPCC) memproyeksikan kenaikan temperature minimum $1,4^{\circ} \mathrm{C}$ dan kenaikan muka air laut setinggi $0,2 \mathrm{~m}$ pada tahun 2100 karena perubahan iklim yang disebabkan oleh kegiatan manusia dalam memproduksi emisi gas rumah kaca (Chintiawati, 2013). 3) Apabila dalam proses pembakaran kain perca terjadi kekurangn oksigen maka yang terjadi adalah pembakaran tidak sempurna. Pembakaran tidak sempurna bisa terjadi karena kain perca yang dibakar bertumpuk-tumpuk, pada bagian atas tumpukan berlangsung pembakaran sempurna dan pada bagian bawah tumpukan hanya ada sedikit oksigen sehingga berlangsung pembakaran tidak sempurna dan dihasilkan gas karbon monoksida (CO). Ciri-ciri dari gas $\mathrm{CO}$ ini tidak berbau dan tidak berwarna sehingga sulit dikenali di lingkungan sekitar, namun bersifat racun bagi tubuh manusia dan efek dari paparan gas karbon monoksida bisa mengakibatkan kematian. Gas karbon monoksida (CO) berpengaruh bagi kesehatan manusia karena bersifat racun terhadap darah, system pernapasan, dan syaraf. Daya ikat hemoglobin terhadap CO sekitar 200 kali lebih besar daripada daya ikat hemoglobin terhadap oksigen (Maleiva, Sitorus, \& Jati, 2015). 4) Penyimpanan kain perca yang tidak terpakai bisa menjadi sarang bagi tikus sedangkan kain perca yang dibuang di ligkungan berupa gumpalan-gumpalan yang bercampur dengan jenis sampah lainnya merupakan media yang baik bagi berkembangnya bibit-bibit penyakit. 
5) Kain perca yang dibuang di lingkungan terbuka seperti di saluran air tidak akan hancur, tapi akan bergabung bersama tanah dan sampah lainnya membentuk gumpalan-gumpalan yang menyumbat saluran irigasi atau selokan-selokan yang dapat menyebabkan bencana banjir. Selanjutnya kumpulan dari kain perca yang bercampur dengan sampah-sampah plastik akan mengganggu resapan air ke dalam tanah. Selain itu pembuangan sampah pada tempat yang tidak tepat akan menghilangkan nilai keindahan lingkungan.

Survei lapangan dilakukan di Desa Sumber Baru pada radius $1 \mathrm{~km}$ dari balai kampung terdapat empat penjahit rumahan. Berdasarkan hasil survei bahwa kain perca yang dihasilkan dari sisa-sisa menjahit pakain tidak dimanfaatkan lagi, melainkan dikumpulkan dalam karung kemudian ditimbun atau dibakar agar tidak memenuhi rumah. Penjahit tidak menghitung banyaknya kain perca yang dihasilkan dalam tiap tahun, tetapi rata-rata di rumah penjahit ditemukan dua karung berukuran $45 \mathrm{~cm} \times 75 \mathrm{~cm}$ berisi kain perca yang belum dibuang. Ada salah satu penjahit yang menyatakan bahwa kain perca yang masih cukup lebar sekitar $50 \mathrm{~cm}$ dikumpulkan lalu digunakan sebagai lap oli di bengkel. Padahal ada beberapa prinsip yang dapat diterapkan dalam pemanfaatan limbah, seperti: reduce, reuse, recycle, dan replace (Marliani, 2015). Reduce yaitu kegiatan pengurangan sampah dengan meminimalkan barang yang digunakan, karena semakin banyak barang yang digunakan maka semakin banyak sampah yang dihasilkan. Reuse yaitu kegiatan menggunakan kembali barang-barang yang sudah dipakai atau tidak menggunakan barang hanya untuk sekali pakai sehingga dapat memperpanjang waktu pemakaian barang sebelum barang tersebut rusak menjadi sampah. Recycle yaitu mendaur ulang kembali barang-barang yang sudah tidak terpakai menjadi barang baru yang lebih bermanfaat sehingga mengurangi jumlah sampah yang tidak dapat diuraikan serta menghemat energi dan juga bahan mentah. Contoh daur ulang ini dapat digunakan untuk mengolah limbah kain perca menjadi barang-barang baru yang bermanfaat tanpa harus menggunakan kain baru yang diproduksi dari pabrik. Replace yaitu upaya mengganti barang-barang yang hanya sekali pakai dengan barang-barang yang dapat digunakan berulang kali, misalnya: menggunakan kain untuk membungkus kado daripada kertas, menggunakan keranjang belanja daripada plastik.

Berdasarkan prinsip-prinsip pemanfaatan limbah anorganik di atas maka kain perca dapat dimanfaatkan kembali menjadi benda yang bermanfaat dan bahkan bisa membuka lapangan usaha bagi warga sekitar yang nantinya bisa menjadi sumber perekonomian. Bendabenda yang bisa dihasilkan dari pengolahan kain perca contohnya aksesoris, seperti: bross, bandana anak-anak, jepit rambut, kalung, dan lain sebagainya. Hasil kerajinan dari kain perca yang dibuat dengan keterampilan yang bagus akan dihasilkan barang kerajinan yang tidak hanya layak untuk digunakan sendiri tetapi juga memiliki nilai jual di pasaran. Dengan demikian pengolahan kain perca bisa mengurangi limbah dan menambah nilai guna serta nilai ekonomis suatu barang. Seperti kegiatan yang telah dilakukan di kampung Sumberejo, Pangkal Surabaya bahwa dengan memberikan pembekalan kepada masyarakat dengan pemanfaatan limbah plastik dan kain perca menjadi kerajinan tangan dapat menambah nilai ekonomis suatu barang yaitu kerajinan tangan dalam bentuk bross (Anindita, Setiawan, Asri, \& Sari, 2017). Dengan demikian pengolahan kain perca menjadi barang-barang bermanfaat dapat membuka peluang bisnis bagi warga sekitar yang sudah terampil. Selanjutnya produk yang dihasilkan dari limbah kain perca dapat dikenalkan kepada masyarakat melalui pameran Dinas Koperasi ataupun UKM seperti yang telah dilakukan di Desa Tegalgondo oleh kelompok usaha kecil yang menghasilkan kelompok usaha mengelola kain perca dari sisa kain para penjahit yang ada di sekitar desa untuk dimanfaatkan menjadi asesoris dan pernak pernik hiasan (Rahadjeng, Latifah, \& Andharini, 2015). Selain dengan cara tradisional promosi dan pemasaran di era saat ini juga bisa dilakukan melalui media sosial ataupun ecomerce sehingga lebih dikenal masyarakat secara luas.

Berdasarkan permasalahan tersebut maka perlu diadakan pelatihan keterampilan kain perca terhadap Ibu-ibu PKK di Desa Sumber Baru Kecamatan Seputih Banyak. Tujuan dari 
kegiatan pengabdian masyarakat ini antara lain 1) Memberikan edukasi terhadap warga di Desa Sumber Baru tentang bahaya limbah anorganik berupa kain perca, dan 2) melatih Mitra dalam mengolah kain perca menjadi barang-barang yang memiliki nilai guna dan nilai ekonomis.

\section{METODE PELAKSANAAN}

Metode yang digunakan dalam kegiatan ini adalah PRA (Participatori Rural Appraisal) sehingga melibatkan masyarakat setempat dalam seluruh kegiatan yang dilaksanakan. Huanepi, Dharmawibawa \& Asy'ari (2018) penggunaan metode ini bertujuan agar masyarakat dapat saling berbagi, meningkatkan, dan menganalisi pengetahun mereka tentang kondisi dan kehidupan masyarakat, membuat rencana, bertindak, mengevaluasi dan merefleksi. Prosedur kerja yang dilakukan dalam kegiatan pengabdian kepada masyarakat dimulai dari perencanaan sampai tindakan.

\section{Perencanaan:}

a. Melakukan survei lapangan di Desa Sumber Baru Kecamatan Seputih Banyak untuk mencari tahu tentang pemanfaat kain perca sisa dari penjahitan baju rumahan.

b. Koordinasi dengan Kantor Kelurahan Kampung Sumber Baru untuk mengondisikan jadwal pelatihan dengan masyarakat yang merupakan perwakilan dari ibu-ibu PKK.

c. Menyediakan materi ajar untuk memberikan edukasi tentang bahaya limbah anorganik tertama kain perca serta cara penanggulangannya.

d. Menyiapkan peralatan dan bahan-bahan untuk kegiatan pelatihan.

Tabel 1. Alat dan bahan keterampilan kain perca

\begin{tabular}{lllr}
\hline No. & Alat dan bahan & Satuan & Jumlah \\
\hline 1. & Gunting & Buah & 3 \\
2. & Cutter & Buah & 3 \\
3. & Penggaris & Buah & 3 \\
4. & Jangka dan Busur & Set & 1 \\
5. & Kertas kardus & Lembar & 3 \\
6. & Korek api & Buah & 3 \\
7. & Lilin & Batang & 3 \\
8. & Tang penjepit & Buah & 1 \\
9. & Jarum jahit tangan & Lusin & 2 \\
10. & Benang jahit & Gulung & 4 \\
11. & Lem tembak & Buah & 3 \\
12. & Manik-manik & Lusin & 6 \\
13. & Rantai hias & Meter & 3 \\
14. & Peniti & Lusin & 4 \\
15. & Kain flannel & Meter & 1 \\
16. & Kain Perca & Kantong plastik & 3 \\
\hline
\end{tabular}

\section{Tindakan}

a. Memberikan penyuluhan atau edukasi kepada warga Desa Sumber Baru tentang bahaya limbah anorganik terutama kain perca serta cara penanggulangannya.

b. Memberikan pelatihan pemanfaatan kain perca berupa keterampilan membuat bross dan bandana.

\section{HASIL DAN PEMBAHASAN}

Kegiatan pengabdian masyarakat ini dilakukan di Desa Sumber Baru Kecamatan Seputih Banyak, Kabupaten Lampung Tengah yang dilaksanakan pada hari Senin, 25 Februari 2019 yang berlokasi di Balai Kampung Suber Baru. Kegiatan ini dilakukan oleh tiga dosen STMIK Pringsewu yang berperan sebagai nara sumber sekaligus pendamping 
palatihan kegiatan. Kegiatan ini di hadiri oleh sebelas peserta pelatihan yang terdiri dari perwakilan ibu-ibu PKK Desa Sumber Baru, diantaranya: istri kepala kampung, istri kepala lingkungan, dan para kader PKK lainnya.

PKK (Pendidikan Kesejahteraan Keluarga) adalah organisasi kemasyarakatan yang memberdayakan wanita untuk turut berpartisipasi dalam pembangunan Indonesia. Namun, sesuai dengan perkembangannya, program pemberdayaan perempuan kemudian diarahkan untuk mewujudkan kemitrasejajaran antara laki-laki dan perempuan dalam kehidupan berkeluarga, bermasyarakat, berbangsa dan bernegara sehingga PKK merupakan sebuah organisasi yang melibatkan partisipasi perempuan dan laki- laki dalam upaya mewujudkan keluarga sejahtera (Aslichati, 2011). PKK sebagai gerakan pembangunan masyarakat bermula dari seminar Home Economic di Bogor tahun 1957. Kesejahteraan keluarga menjadi tujuan utama PKK. Upaya untuk meningkatkan kesejahteraan keluarga PKK melalui 10 program pokok, yaitu: penghayatan dan pengamalan Pancasila, gotong royong, pangan, sandang, perumahan dan tatalaksana rumah tangga,pendidikan dan ketrampilan, kesehatan, pengembangan kehidupan berkoperasi, kelestarian lingkungan hidup, dan perencanaan sehat.

Pelatihan keterampilan kain perca merupakan bagian dari 10 program pokok PKK untuk kesejahteraan keluarga yang telah diuraikan di atas, diantaranya: 1) kelestarian lingkungan hidup dengan memberikan edukasi tentang bahaya dari limbah anorganik (kain perca) terhadap lingkungan seperti isu pemanasan global; 2) kesehatan, yaitu limbah dari kain perca yang tidak ditangani dengan baik bisa menjadi sumber penyakit; 3) pendidikan dan keterampilan dengan memberikan pelatihan pengolahan kain perca menjadi barang yang bermanfaat bahkan bernilai ekonomi sehingga diharapkan mampu memberilkan peluang usaha. Hal ini seperti pengabdian yang telah dilakukan di Desa Krajan Timur, Kecamatan Jelbuk, Kabupaten Jember, Jawa Timur bahwa dengan memperdayakan masyarakat miskin di desa tersebut dengan memberian keterampilan pembuatan bros layak jual masyarakat juga memeperoleh pengetahuan untuk menjaga lingkungan dengan cara mendaur ulang limbah konveksi (Devanti, 2017).

Edukasi yang diberikan tentang bahaya limbah kain perca antara lain adalah dampakdampak yang bisa ditimbulkan seperti pembakaran limbah yang mengasilkan gas $\mathrm{CO}_{2}$ sebagai emisi gas rumah kaca yang dapat menyebabkan pemansan global yaitu penyebab suhu rata-rata bumi meningkat sehingga mencairnya es di kutub-kutub bumi dan naiknya permukaan air laut serta terjadinya perubahan iklim yang tidak dapat diprediksi. Dampak dari pemanasan global tersebut akan mempengaruhi kelangsungan mahluk hidup di bumi. Dampak lainnya adalah tentang kesehatan, kesuburan tanah, dan bencana banjir. Namun apabila kain perca tersebut diatasi dengan bijak maka dampak-dampak negatif dari limbah tersebut dapat dikurangi, bahkan yang tadinya dianggap sampah tidak berguna akan menjadi barang yang berguna dan bernilai jual.

Setelah selesai edukasi tentang dampak limbah kain perca dan peluang usaha dari daur ulang kain limbah maka para peserta diberi pelatihan tentang keterampilan pengolahan kain perca menjadi barang-barang berguna. Adapun barang-barang yang dihasilkan dari pelatihan ini antara lain: bross dada, bross dagu, dan bandana. Dalam pelatihan ini semua peserta diajarkan bagaimana cara mebuat barang tersebut satu persatu secara serentak mulai dari cara memotong kain, menjahit, mengelem, sampai siap digunakan.

1. Bross Dada

Bross dada yang diajarkan dalam pelatihan ini adalah bross dada dengan motif bunga. Langkah yang dilakukan adalah mebuat pola 5 buah lingkaran dengan diameter $7 \mathrm{~cm}$ pada kain perca. Lingkaran tersebut dibuat dengan jangka sorong atau benda yang berbentuk lingkaran pada kardus, kemudian kardus dipotong melingkar sesuai pola. Selanjutnya kardus ditempelkan pada kain dengan jarum pentul, lalu kain dipotong. Setelah diperoleh lima pola lingkaran dari kain maka setiap potongan kain dilipat pada sumbu simetrinya sebanyak dua kali dan bagian sisi lingkarannya dijahit lalu diserut, kemudian dilanjutkan dengan kain 
kedua samapi habis. Jika semua kain sudah menyatu dan membentuk bunga maka jahitan disimpul mati. Bagian tengah dari bunga yang berlubang ditutup dengan manik-manik. Lalu bross di tempel pada kain flannel yang diberi peniti.

Hasil kegiatan menunjukkan bahwa Mitra dengan cepat memahami cara kerja pembuatan Bross Dada, selain itu mereka juga dapat mengkombinasikan warna serta membuat model-model lain. Adapun proses seperti yang pada gambar berikut ini;
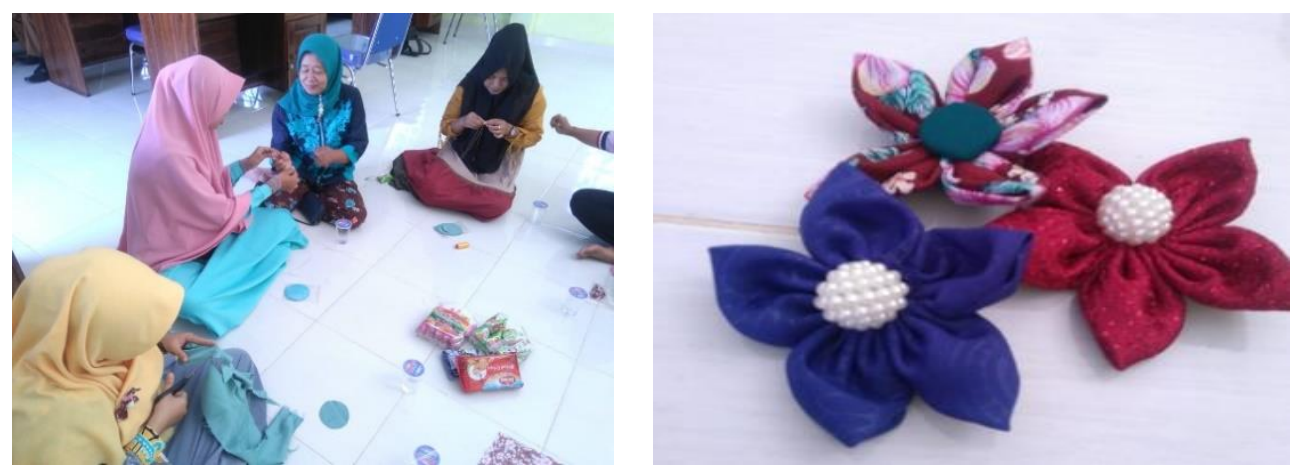

Gambar 1. a. Proses pembuatan bros dada. b. Hasil dari kegiatan pelatihan bros dada. (Sumber Gambar: Doc. Pengabdian)

\section{Bross Dagu}

Saat ini bross dagu merupakan bross yang lagi trend di kalangan anak muda maupun ibu-ibu. Bros dagu dalam pelatihan ini berbentuk pita kecil. Cara membuat bross dagu cukup sederhana, yaitu memotong kain perca membentuk sebuah persegi panjang dengan ukuran $6 \mathrm{~cm} \times 7 \mathrm{~cm}$. Kemudian melipat ujung-ujung dari setiap sisi persegi panjang yang sejajar ke arah sumbu simetrinya, lalu lipatan yang panjang disatukan di tengah-tengah dan dijahit lalu diserut membentuk pita. Untuk menutupi benang yang terlihat bagian tengah pita bisa ditutup dengan kain lagi, kemudian bagian bawah pita dikaitkan dengan rantai pengait yang menjuntai dan diapasang manik-manik, selanjutnya pita ditempel pada kain flannel yang diberi peniti.
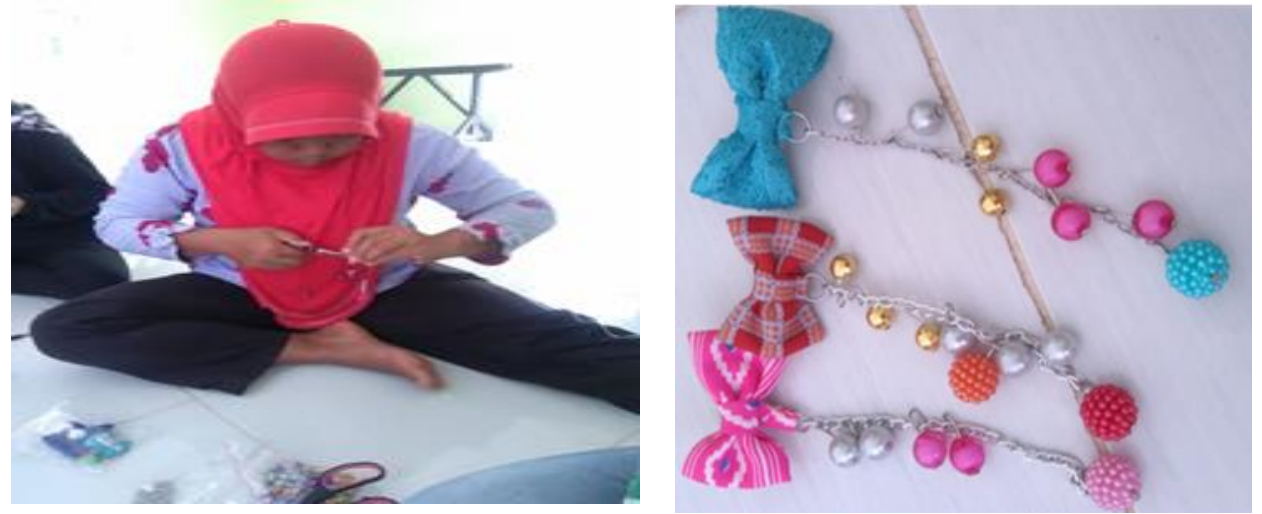

Gambar 2. a. proses pembautan bros dagu. b. Hasil dari kegiatan pelatihan bros dagu. (Sumber Gambar: Doc. Pengabdian)

Proses pembuatan antara bros dagu dan dada pada prinsipnya tidak terlalu jauh berbeda, umumnya bros dagu bentuknya lebih sederhana dan ada penambahan hiasan seperti manikmanik atau mutiara mitasi. 


\section{Bandana}

Bandana dalam pelatihan ini motifnya sama dengan bros dada yaitu bunga, maka cara membuatnya sama persis. Jika kain flanelnya pada bross dada dikaitkan dengan peniti, namun pada bandana kain flenel dilem pada tali bandana. Kain perca yang digunakan dalam kegiatan pelatihan ini dikumpulkan dari salah satu penjahit di desa Sumber Baru. Seluruh peserta antusias mengikuti acara pelatihan, memperhatikan langkah demi langkah cara membuat bross dan bandana, bahkan tidak sungkan untuk bertanya apabila belum paham atau belum berhasil membuat salah satu karya. Kendala dalam kegiatan pelatihan ini adalah keterbatasan alat berupa tang penjepit untuk memasang manik-manik pada rantai hias sehingga para peserta saling tunggu antara satu dengan lainnya. Dengan ketekunan dan kesabaran untuk berlatih maka setiap peserta mampun menghasilkan karya meskipun masih ada satu peserta yang belum rapi menjahitnya. Aktivitas peserta pelatihan yang terdiri dari ibu-ibu PKK ditunjukkan pada gambar 1 dan hasil pelatihan keterampilan kain perca ditunjukkan pada gambar 2.

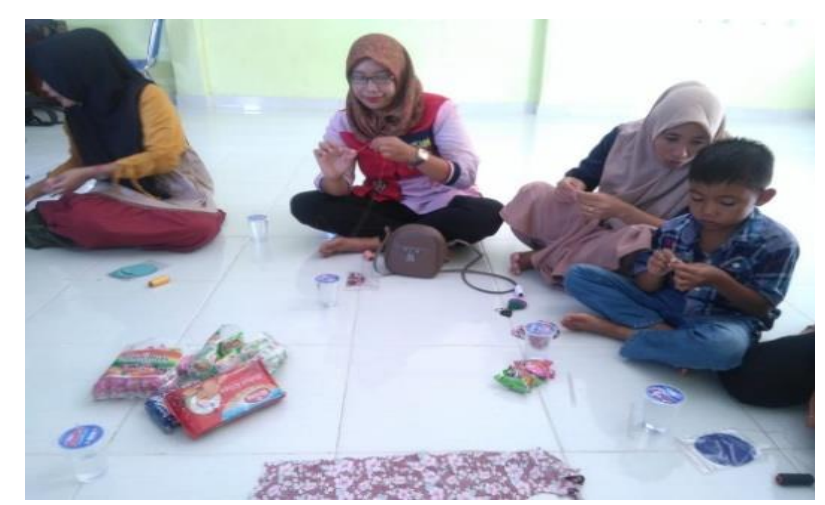

Gambar 3. Proses pelatihan keterampilan kain perca pembuatan bandana (Sumber Gambar: Doc. Pengabdian)

Pada saat proses pembuatan banda, kerja mitra lebih cepat karena mitra sudah mulai terbiasa membuat bagian-bagian dari bros dagu dan dada. Bandana yang dihasilkan memiliki variasi warna dan model yang lebh simpel dari bros dagu dan dada.

\section{KESIMPULAN}

Berdasarkan hasil kegiatan pengabdian kepada masyarakat di Desa Sumber Baru dapat disimpulkan bahwa masyarakat sekitar memahami tentang bahaya limbah anorganik terutama kain perca serta cara penanggulangannya sehingga lebih peduli terhadap lingkungan. Dengan adanya pelatihan tersebut menjadikan ibu-ibu PKK lebih terampil memanfaatkan limbah kain perca menjadi aksesoris seperti bros dan bandana.

\section{SARAN}

Kegiatan selanjutnya perlu pendampingan dan pelatihan cara pemasaran produk yang dihasilkan dari kreativitas kain perca melalui media online sehingga dapat menjadikan sumber penghasilan bagi masyarakat di Desa Sumber Baru.

\section{UCAPAN TERIMA KASIH}

Terima kasih kepada STMIK Pringsewu sebagai donatur dalam kegiatan pengabdian masyarakat serta terima kasih kepada seluruh Aparat Desa Sumber Baru dan warga sekitar yang telah berpartisipasi dalam kegiatan ini sehingga terlaksana dengan baik.

\section{DAFTAR PUSTAKA}

Anindita, G., Setiawan, E., Asri, P., \& Sari, D. P. (2017). Pemanfaatan Limbah Plastik dan

Kain Perca Menjadi Kerajinan Tangan Guna Meningkatkan Kualitas Sumber Daya 
Manusia. Seminar MASTER PPNS, 2(1), 173-176. Retrieved from https://journal.ppns.ac.id/index.php/SeminarMASTER/article/view/310

Aslichati, L. (2011). Organisasi pemberdayaan dan kesejahteraan keluarga sebagai sarana pemberdayaan perempuan. Jurnal Organisasi Dan Manajemen, 7(1), 1-7. Retrieved from http://www.jurnal.ut.ac.id/index.php/jom/article/view/77

Chintiawati, R. (2013). Estimasi dan Proyeksi Emisi Gas Rumah Kaca dari Pengelolaan Sampah di Kota Tangerang dengan Pendekatan Metode IPCC. Skripsi.

Devanti, Y. M. (2017). Pemanfaatan Limbah Konveksi Untuk Meningkatkan Pendapatan Rumah Tangga Miskin (RTM). Jurnal Pengabdian Masyarakat Ipteks, 3(1). Retrieved from

http://jurnal.unmuhjember.ac.id/index.php/PENGABDIAN_IPTEKS/article/view/998

Fauziawan, A. I. (2018). Estimasi Emisi Gas Karbondioksida (Co2) Dari Sektor Limbah Padat Di Kabupaten Karangasem Dengan Metode FIRST ORDER DECAY (FOD). Biota: Jurnal Ilmiah Ilmu-Ilmu Hayati, 2(1), 37-45. Retrieved from http://ojs.uajy.ac.id/index.php/biota/article/view/1688

Huanepi, Dharmawibawa D.I., \& Asy'ari M. (2018) Pemberdayaan Kelompok Budidaya Jamur Tiram Dalam Pemanfaatan Limbah Baglog Menjadi Pupuk Organik. Prosiding Seminar Nasional dan Diskusi Panel Multidisiplin Ilmu. 1(1) http://www.proceeding.unindra.ac.id/index.php/dispanas2018/article/view/21

Maleiva, L. T. N., Sitorus, B., \& Jati, D. R. (2015). Penurunan Konsentrasi Gas Karbon Monoksida Dari Kendaraan Bermotor Menggunakan Adsorben Zeolit Alam. Jurnal Kimia Khatulistiwa, 4(1). Retrieved from http://jurnal.untan.ac.id/index.php/jkkmipa/article/view/11725

Marliani, N. (2015). Pemanfaatan limbah rumah tangga (sampah anorganik) sebagai bentuk implementasi dari pendidikan lingkungan hidup. Formatif: Jurnal Ilmiah Pendidikan MIPA, 4(2). Retrieved from https://journal.lppmunindra.ac.id/index.php/Formatif/article/view/146

Rahadjeng, E. R., Latifah, S. W., \& Andharini, S. N. (2015). IbM Usaha Jahitan dan Pengelolaan Kain Perca. Jurnal Dedikasi, 12. Retrieved from http://ejournal.umm.ac.id/index.php/dedikasi/article/view/2479

Samiaji, T. (2010). Upaya mengurangi CO2 di atmosfer. Berita Dirgantara, 10(3). Retrieved from http://jurnal.lapan.go.id/index.php/berita_dirgantara/article/view/745

Sari, I. R. J., \& Fatkhurrahman, J. A. (2015). Inventori Pencemaran Udara Parameter NonMethane Hidrokarbon (NMHC) di Kabupaten/Kota Propinsi Jawa Tengah. Jurnal Riset Teknologi Pencegahan Pencemaran Industri, 6(2), 59-66. Retrieved from http://202.47.80.55/jrtppi/article/view/1241

Sihombing, S. R. (2012). Potensi Penurunan Emisi Gas Rumah Kaca Pada Industri Gula (Studi Kasus PT PG Rajawali II Unit PG Subang). Skripsi, Fateta, IPB.

Taufiq, A. (2015). Sosialisasi Sampah Organik Dan Non Organik Serta Pelatihan Kreasi Sampah. Asian Journal of Innovation and Entrepreneurship, 4(01), 68-73. Retrieved from https://journal.uii.ac.id/ajie/article/view/7898/6907

Widyati, E. (2013). Pentingnya keragaman fungsional organisme tanah terhadap produktivitas lahan. Tekno Hutan Tanaman, 6(1), 29-37. Retrieved from https://www.forda-mof.org/files/Tekno_6.1.2013-4.EnnyWidyati.pdf 